\title{
The Principalship: Essential Core Competencies for Instructional Leadership and Its Impact on School Climate
}

\author{
Dorrell J. Ross ${ }^{1,2}$, Jeffry A. Cozzens ${ }^{1,2}$ \\ ${ }^{1}$ School of Education, Freed-Hardeman University, Henderson, Tennessee, USA \\ ${ }^{2}$ School of Education, Freed-Hardeman University, Memphis, Tennessee, USA \\ Correspondence: Dorrell J. Ross, School of Education, Freed-Hardeman University, Tennessee, USA.
}

Received: April 19, 2016 Accepted: April 22, $2016 \quad$ Online Published: July 5, 2016

doi:10.11114/jets.v4i9.1562 URL: http://dx.doi.org/10.11114/jets.v4i9.1562

\begin{abstract}
The purpose of this quantitative study was to investigate teachers' perceptions of principals' leadership behaviors influencing the schools' climate according to Green's (2010) ideologies of the 13 core competencies within the four dimensions of principal leadership. Data from the Leadership Behavior Inventory (Green, 2014) suggest 314 teachers perceive that 13 core competencies positively influence school climate through effective leadership. Teachers' perceptions of principals exhibiting the 13 core competencies suggested that professionalism ranked as the most prevalent behavior among principals. A multiple regression analysis determined public teachers perceived that diversity, one of the 13 core competencies that involve principals respecting the ideas of others and eliminating biases, had the greatest impact on school climate. An independent sample $t$-test revealed that 11 of the 13 core competencies were statistically significant among private and public teachers' perceptions, but a Bonferroni adjustment determined that only five core competencies were significant. Further analyses revealed that there was no statistically significant evidence to support teachers' perceptions of school climate differing between private and public schools.
\end{abstract}

Keywords: school climate, culture, teachers' perceptions, 13 core competencies, transformational leadership, instructional leadership, diversity, education reform

\section{Introduction}

Since the initial studies in the field of educational leadership and school success, researchers have paid close attention to the effects of principals' leadership on student achievement and school climate (Green, 2001, 2010, 2012; Hallinger, 2003; Hallinger \& Heck, 2010; Lambert, 1998; Louis, Dretzke, \& Wahlstrom, 2010). Studies suggested principals directly influenced student achievement through constant interactions with the students and the arrangement of classroom sizes, which influenced students' abilities through teachers' instructional strengths (Bossert, Dwyer, Rowan, \& Lee, 1982; Danielson, 2006; Fullan, 2006; Leithwood, Louis, Anderson, \& Wahlstrom, 2004; U.S. Department of Education, 2004). Some researchers asserted that effective principals indirectly influenced student achievement by encouraging teachers to reflect and communicate on pedagogical issues, professional learning communities, and the educational environment (Danielson, 2006; Hallinger \& Heck, 2010; Hoy, Sweetland, \& Smith, 2002; Levine \& Marcus, 2007; Murphy, Elliot, Goldring, \& Porter, 2007; Louis et al., 2010; Printy, 2008; Wahlstrom \& Louis, 2008; Wiseman, 2014; Witziers, Bosker, \& Kruger, 2003). Although principals' leadership behaviors influenced schools' success, continuous empirical research affirmed that effective principals influenced the school's climate and culture through teacher collaboration, professional development, and policies and procedures (Louis, Leithwood, Wahlstrom, \& Anderson, 2010).

Education reform in the United States has focused on shifting the existing educational practice to a system that closes the achievement gaps among diverse populations (Louis et al., 2010). Restructuring in the educational system has forced leadership to evolve as quality instruction, instructional programs, and international competition have progressed. The role of an instructional leader in shaping the context for teaching and learning is not a novel concept. Research concerning school leaders and their influences on teaching, learning, and sustainable leadership has evolved to reflect and respond to the growing need to define the doctrines of school leadership influencing student learning (Copland, 2000; Cook, 2014; Edmonds, 1979; Ward, 2013). Edmonds (1979) reported that instructional leadership theory had its practical study in elementary schools of poor urban communities where students succeeded under (a) effective 
instructional leadership that restricted disruptions and (b) stakeholders who valued high expectations for teaching and learning. Instructional leaders found it beneficial to maintain a positive working relationship among teachers, students, parents, and community leaders, and chose to focus on school climate because it ultimately affected the school's culture and student achievement (Cohen, McCabe, Michelli, \& Pickeral, 2009; Cozzens, 2004; MacNeil, Prater, \& Busch, 2009). Instructional leaders recognized that school climate "cannot be seen or touched, only felt" (Villani, 1999, p. 103). School climate is the quality of institutional life promoted by student learning through the emotional, physical, and social safeties of the school (National School Climate Council, 2007). Principals' leadership that focused on the school's climate, culture, and instructional practices to diminish the educational gaps confidently forecasted the degree to which collaboration among teachers improved student achievement and the school's environment (Friend \& Cook, 2009; Gupton, 2003; Marks \& Printy, 2003; Schein, 1985, 2004).

Any discussion that involves effective leadership for the $21^{\text {st }}$ century principal began with the work of James Macgregor Burns, who first introduced transforming leadership theory in his research on political leaders. Burns (1978) analyzed the abilities of leaders who engaged with their employees in ways that stimulated them to new levels of liveliness, promise, and moral purpose. Bass (1985) and several colleagues expounded on the work of Burns, changing the name of transforming leadership to transformational leadership (Bass, 1985; Bass \& Avolio, 1994; Bass \& Riggio, 2006; Riggio, 2009; Stewart, 2006). Bass (1985) insisted that transformational leadership consisted of four behavioral components: (a) idealized influence, (b) inspirational motivation, (c) intellectual stimulation, and (d) individualized consideration. Transformational leadership, though a theoretical model originating in studies of corporate and political leadership, appeared suitable to the needs of schools as they evolved and restructured in response to academic needs across the nation (Hallinger, 2003). Specifically for application in the school system, transformational leaders took full responsibility for their leadership and went beyond the norms to satisfy the needs of followers to improve organizational effectiveness (Afshari, Bakar, Luan, \& Siraj, 2012; Boerner, Eisenbeiss, \& Griesser, 2007; Dawson \& Rakes, 2003; Hallinger, 2003; Leithwood, 1992; Leithwood \& Jantzi, 2006; Liontos, 1992; Marks \& Printy, 2003; Ross \& Gray, 2006b; Stewart, 2006). Transformational leadership behaviors that focused on people and organizational needs were more effective than behaviors of transactional leadership that focused on technical problem solving (Afshari et al., 2012; Rudd, Kent, Blair, \& Schuele, 2009). In education, transformational leadership is the most ideal leadership style to strengthen debate, invite understanding, and contribute greatly towards teachers' professionalism through innovation and facilitated learning (Ross \& Gray, 2006a; Aydin, Sarier, \& Uysal, 2013). Additionally, a meta-analytic study (i.e., combining and analyzing small studies) on instructional leadership research concluded that student achievement is associated with instructional and transformational leadership, and instructional leadership is the greatest predictor for success (Robinson, Lloyd, \& Rowe, 2008). Principals who practiced instructional and transformational leaderships improved the overall conditions of schools, especially the school's climate, and inspired stakeholders to support the school's goals (Aydin et al., 2013; Gray \& Lewis, 2013; Hallinger, 1992, 2003; Mendels, 2012; Tobin, 2014).

\subsection{Background to the Study}

For decades, politicians have placed education as a central focus for improving social and educational inequities including global competition (Louis et al., 2010; Standerfer, 2006). Lyndon Baines Johnson, the $36^{\text {th }}$ U.S. President, established the Elementary and Secondary Education Act (ESEA) of 1965 to provide full educational opportunities to students who were underprivileged in order to strengthen the American educational system and compete with the technological advancements of the Soviet Union's launch of Sputnik, a Russian satellite (Scott, 2007; Standerfer, 2006; Straus, 2015; Weaver, 2006).

After the birth of ESEA, George Walker Bush, the $43^{\text {rd }}$ U.S. President, established and reauthorized the act by signing into law the No Child Left Behind Act (NCLB) of 2001. The development of NCLB increased accountability among stakeholders to enhance teaching and learning, and provided instructional leaders with the knowledge and techniques to enhance scholastic practices, culture, and school climate (Hull, 2002; Louis et al., 2010; NCLB, 2002; Simpson, Lacava, \& Graner, 2004). Additionally, NCLB stimulated precision within a curriculum, established yearly proficiency targets, attendance and graduation rates, and declared that all educators must be certified and highly qualified to continue receiving federal funds for educational improvements (Editorial Projects in Education Research, 2011a, 2011b; Hull, 2002; NCLB, 2002; Powell, Higgins, Aran, \& Freed, 2009; Simpson et al., 2004; Spelling, 2007; The White House, 2014). NCLB represented the greatest extension of the government's control in schools through mandated assessments and accountability structures (Hull, 2002). However, the policies of NCLB failed to improve the educational disparities among diverse populations using federal funds and research-based practices (Strauss, 2015).

Although No Child Left Behind (NCLB) covered several federal mandates and educational programs, the act's requirements for accountability and school improvement received greater attention. As an attempt to broaden Bush's educational plans of NCLB, Barack Hussein Obama, the $44^{\text {th }}$ U.S. President, initiated Race to the Top (RTT). RTT provided incentives for states to restructure their educational system, while NCLB required states to restructure their 
system to continue receiving funds that were already provided (Lohman, 2010; NCLB, 2002). The policies of NCLB and the educational program objectives of RTT were to develop rigorous standards and quality assessments, create appropriate data systems providing stakeholders with information about student progress, and increase resources needed to improve low performing schools (Lohman, 2010; Miller \& Hanna, 2014; The White House, 2014). Since policymakers have required an increase in students' academic performance and job readiness skills, instructional leaders have focused on common assessments, content standards, instructional strategies, federal policies, professional development, and leadership styles (DuFour, Eaker, \& Burnett, 2002; Hallinger, 2003; Hallinger \& Heck, 2010; Lambert, 1998, 2002, 2006; Levine \& Marcus, 2007; Lohman, 2010; Miller \& Hanna, 2014; Murphy et al., 2007; NCLB, 2002).

\subsection{Statement of the Problem}

Successful principals were transparent about decisions to promote sustainable leadership, accountability, and collaboration through the modifications of leadership styles and instructional practices according to circumstances in their schools (Blasé \& Blasé, 1998; Bruce, 2011; Calik, Sezgin, Kavgaci, \& Kilinc, 2012; Cook, 2014; Green, 2001, 2010; Hallinger, 2003; Hallinger and Heck's, 2010; Hoerr, 2005; Leithwood \& Jantzi, 2006; Marzano, Waters, \& McNulty, 2005). Leaders developed styles and characteristics according to environmental conditions; thus social, economic, and cultural factors often determined the conditions of effective leadership styles (Hackman \& Wagman, 2007; Lunenburg, 2011; Sergiovanni, 2005). While school leaders and their skill levels varied because of training and experience, research pointed to specific aspects of effective leadership styles that yielded high achievement outcomes. Principals who exhibited leadership styles that did not lead to results had an adverse effect on teacher efficacy, a positive school environment, and student achievement (Capelluti \& Nye, 2004). Fundamentally, if the schools' organizational structure is to increase positively, principals' leadership styles must first change. A thorough understanding of effective leadership styles and practices broadens the knowledge of and investment in behaviors influencing student achievement, teacher efficacy, and school climate.

\subsection{Purpose of the Study}

The goal of all schools is to increase student success through a positive school climate, effective leadership skills, and instructional best practices (Fullan, 2006; Leithwood et al., 2004; Spillane, 2006). The purpose of this research was to investigate the extent of teachers' perceptions of principals' leadership behaviors connected to a healthy school climate, and how those behaviors were related to Green's (2010) 13 core competencies (i.e., assessment, collaboration, curriculum and instruction, diversity, inquiry, instructional leadership, learning community, organizational management, professional development, professionalism, reflection, unity of purpose, and visionary leadership). Research has acknowledged that leadership serves as a catalyst for school improvement shaped by historical and current conditions in schools. Principals who sought to improve the entire structure of schools attempted to build trusting relationships and shared leadership practices, exhibit effective research-based leadership, and focus on the collective evidence of student learning (Hallinger \& Heck, 2010).

\subsection{Significance of the Study}

Green (2001) noted 13 characteristics of nurturing schools and clustered those characteristics into four themes: (a) student-teacher relationships, (b) professionalism among administration, faculty, and staff, (c) environment of the school and classroom, and (d) students' feelings about themselves. In some schools, the themes had a positive effect on students' behavior, attendance, and achievement (Green, 2001). Research suggested that the quality of schooling improved when behaviors of school leaders reflected the four themes, thus supporting student's social and emotional development (Green, 1998, 2001). Green (2010) ultimately and more specifically grouped the 13 characteristics of nurturing schools to create the 13 core competencies that lead to the formation of the four dimensions: (a) Understanding Self and Others, (b) Understanding the Complexity of Organizational Life, (c) Building Bridges through Relationships, and (d) Engaging in Leadership Best Practices.

\subsection{Relationship to Prior Research}

Former research has indicated that the 13 core competencies of leadership drove the practices of instructional leaders' organizational success (Green, 2010). These same competencies were the building blocks for the foundation of the four dimensions of principal leadership written in Green's (2010) book, The Four Dimensions of Principal Leadership: A Framework for Leading $21^{s t}$ Century Schools. The goal of Green's framework was to provide principals with the knowledge of establishing effective schools through shared leadership and collective responsibility of stakeholders. Principals had the duty of cultivating an educational environment that empowered all stakeholders while abiding by policies and practices set forth by national and state standards. Policies and practices that were clear and consistent through the Interstate School Leader Licensure Consortium (ISLLC) provided guidance for principals to maintain and increase the school climate and culture, student achievement, teacher retention, and job satisfaction (Green, 2001, 2010, 
2012; ISLLC, 2008, 2014; Kelley, Thornton, \& Daugherty, 2005; NCLB, 2002).

Ivie's (2007) research study concluded that when school leaders were skillful in the core competencies of visionary leadership, unity of purpose, establishing professional learning communities, organizational management, and instructional leadership, specialized learning communities were considerably developed. Fee (2008) determined that principals who exhibited model behaviors informed by the 13 core competencies also enhanced teaching and learning and teacher motivation (Farmer, 2010). According to Farmer's (2010) study, when principals valued and implemented the 13 core competencies, teachers were more likely to value the core competencies that influenced job satisfaction, self-efficacy, collective teacher efficacy, and intrinsic motivation. Prior research and review of literature had found correlations within the 13 core competencies as they related to leadership, job satisfaction, motivation, academic achievement, culture, and school climate. Furthermore, this current research adequately linked past studies concluding that principals who exhibited the 13 core competencies of leadership within the four dimensions of principal leadership positively affected school climate.

\subsection{Assumptions}

Researchers suggested that there were indirect and direct relationships between principals' leadership and the learning outcomes of students (Danielson, 2006; Lambert, 1998, 2006; Levine, 2005). If highly effective principals strived for quality instruction (Marzano et al., 2005) and exhibited behaviors outlined by Green's (2010) 13 core competencies, the schools' climate and students' academic achievements were positively impacted. When principals placed academics and research-based instructional best practices as top priorities, research confirmed that student achievement increased, and the school's climate improved (Cotton, 2000; DuFour et al., 2002; Fullan, 2006; Green, 2010; Leithwood et al., 2004; Spillane, 2006). Ultimately, principals were the key constituents who created a collaborative school culture to improve both teaching and learning.

\section{Method}

\subsection{Research Design}

The purpose of this quantitative study was to investigate (1) whether principals exhibited behaviors informed by the 13 core competencies, and (2) how those behaviors correlated to teachers' perceptions of school climate. The study sought to address the following research questions:

Q1. To what extent do teachers perceive that principals exhibit Green's 13 core competencies?

Q2. Is there a relationship between teachers' perceptions of school climate and Green's 13 core competencies?

Q3. Which of Green's 13 core competencies has the largest impact on school climate?

Q4. Do perceptions of school climate differ between private and public teachers?

The data from the research questions incorporated a mixture of descriptive and inferential statistics that included the following: (a) Pearson product-moment correlation coefficient $(r)$ to determine a linear correlation (e.g., negative, positive or no correlation) between variables, (b) multiple regression analysis to determine the greatest impact, and (c) $t$-test analysis to determine statistically significant differences (Creswell, 2015). The correlational design was chosen for this study because groups were not controlled or randomly assigned (Creswell, 2015; Trochim \& Donnelly, 2008). The research was also cross-sectional because it allowed the researcher to identify perceptions within public and private schools by examining different variables at the same time.

\subsection{Participants}

The participants in this study were approximately 375 teachers (i.e., 250 public and 125 private) from two public high schools, two elementary schools, and three private schools in West and Middle Tennessee. The schools' demographics were as follows: (a) School A - Public High School, $9^{\text {th }}-12^{\text {th }}$ grade level, 86 teachers; (b) School B - Public High School, $9^{\text {th }}-12^{\text {th }}$ grade level, 76 teachers; (c) School C - Public Elementary, Pre-Kindergarten $-5^{\text {th }}$ grade level, 49 teachers; (d) School D - Public Elementary, Pre-Kindergarten $-5^{\text {th }}$ grade level, 39 teachers; (e) School E - Private Lower/Upper School, Pre-Kindergarten $-12^{\text {th }}$ grade level, 71 teachers; (f) School F - Private Lower/Middle, Pre-Kindergarten $-6^{\text {th }}$ grade level, 26 teachers; and (g) School G - Private High School, Pre-Kindergarten $-12^{\text {th }}$ grade level, 28 teachers. The research group or convenience sample only comprised of 314 participating teachers with an overall response rate of $84 \%$ (i.e., 314 out of 375). Public school teachers accounted for 95\% (i.e., 237 out of 250), and private school teachers accounted for $62 \%$ (i.e., 77 out of 125 ).

\subsection{Data Collection Tool}

The primary data collection tool for this study was the Leadership Behavior Inventory (Green, 2014), which was revised by the current researcher from the original Leadership Behavior Inventory (Green, 2006) to improve time completion. 
The original Leadership Behavior Inventory was a 39-item (i.e., three questions per core competency), five-point Likert scale inventory providing demographics of teachers and principals, questions addressing teachers' perceptions of principals according to the 13 core competencies of leadership, and the frequency to which principals exhibited the set competencies. The revised Leadership Behavior Inventory (Green, 2014) was a 26-item (i.e., two questions per core competency), five-point Likert scale inventory that aligned to the same concepts as the original inventory but also included demographics and three school climate questions. The Likert scale for the 26 items was as follows: $1=$ Never, $2=$ Seldom, $3=$ Occasionally, $4=$ Frequently, and $5=$ Always. The four-point Likert scale for the three climate questions was as follows: $1=$ Strongly Disagree, $2=$ Disagree, $3=$ Agree, and $4=$ Strongly Agree . The 13 core competencies of leadership measured with the survey include: (a) assessment, (b) collaboration, (c) curriculum and instruction, (d) diversity, (e) inquiry, (f) instructional leadership, (g) learning community, (h) organizational management, (i) professional development, (j) professionalism, (k) reflection, (l) unity of purpose, and (m) visionary leadership.

\subsection{Data Collection Procedures}

The researcher submitted the proposal to the university's Institutional Review Board (IRB) to conduct research. After approval of the submitted proposal, the researcher: (a) reviewed and submitted documentation to superintendents, directors of schools, and research department coordinators of various districts for potential research requests, (b) contacted principals when instructed that the principals were the final arbiter for the research request, (c) constructed a Google Form, and (d) submitted the Google link to the appropriate Tennessee schools with coded information collecting live data. Due to time constraints, job responsibilities of participants, comfort of confidentiality, cost implications, and accuracy of data, the researcher utilized a password protected electronic survey to maintain participants' anonymity.

Following the school principals' approval to participate in the study, the researcher submitted a Google Form to the principals, and the principals distributed the information through the schools' emailing systems. An electronic consent form was emailed to provide the purpose of research, the clause of confidentiality, time completion of the survey, and contact information for questions or concerns. Participating teachers completed the survey from December 2014 through February 2015 due to the holiday school break and semester testing schedules. Participants were aware that participation was voluntary, and review of responses was acceptable before complete submission.

\subsection{Limitations}

Although the current study was an extension of an existing body of work, limitations were present within the research. First, participation in the research study was strictly voluntary such that the researcher had no control over who was involved in the study. This study included a small sample size and lacked true diversity. Though the current study added to several studies that focused on Green's 13 core competencies, this study was not generalizable to schools or districts outside the sample because there was no random sampling involved.

Second, the researcher had no knowledge of pre-existing relationships between principals and teachers in the study, which could have influenced results. This study examined subject-specific content areas (i.e., English, fine arts, career technical education, physical education, math, science, and social studies) in relation to the teachers' observations of principals and used the Leadership Behavior Inventory (Green, 2014) to collect data. Questions from the inventory were asked based on a five-point Likert scale (e.g., agree, strongly agree, etc.), and constructive qualitative responses were not an option within the survey.

\subsection{Content Validity and Reliability}

Ivie (2007) validated Green's (2006) Leadership Behavior Inventory through peer reviews of 156 educators (i.e., 20 principals and 136 teachers) regarding job satisfaction of teachers and principals implementing core competencies of leadership within various schools (Farmer, 2010). After careful reviews and consideration, 136 teachers completed the survey with a calculated internal consistency alpha coefficient score of $\alpha=.905$ (Ivie, 2007). The internal consistency associated with the scores derived from a scale or a composite score calculating Cronbach's alpha such that, "Computation of alpha is based on the reliability of a test, relative to other tests with the same number of items, and measuring the same construct" (Santos, 1999, p. 1). Ivie's (2007) research determined that the Leadership Behavior Inventory yielded high consistency response rates with Cronbach's alpha coefficients of $\alpha=.938$ for principals and $\alpha$ $=.939$ for teachers. Since the inventory yielded high alpha coefficient scores, it was determined that Ivie's validations of Green's (2006) Leadership Behavior Inventory would provide desirable results for future practice.

\subsection{Current Study Instrument Reliability}

Past researchers determined that Green's (2006) Leadership Behavior Inventory yielded positive internal consistencies and would accurately measure specific characteristics, skills, and qualities of leaders for future results (Farmer, 2010; Ivie, 2007). Table 1 highlights the Cronbach alpha score for each competency (i.e., 2 items per core competency) for the current research. 
Table 1. Reliability Statistics for Each Core Competency

\begin{tabular}{ll}
\hline Variables & Cronbach Alpha \\
\hline Assessment & .74 \\
Inquiry & .75 \\
Instructional Leadership & .82 \\
Unity of Purpose & .82 \\
Visionary Leadership & .84 \\
Diversity & .85 \\
Learning Community & .85 \\
Reflection & .85 \\
Organizational Management & .87 \\
Professional Development & .87 \\
Collaboration & .88 \\
Curriculum and Instruction & .88 \\
Professionalism & .94 \\
\hline
\end{tabular}

The revised 26-item Leadership Behavior Inventory (Green, 2014) collected data from 314 participants, and a Cronbach's alpha coefficient of $\alpha=.980$ was determined. Since the Cronbach's numerical alpha coefficient was .980 , the researcher concluded that the revised inventory would yield similar and highly consistent future outcomes.

\section{Results}

This section provides the results from the data analyses in tabulated descriptive and statistical text.

\subsection{Participating Teachers' Demographic Data}

Table 2 shows the complete summary of 314 participating teachers' demographic statistical results that include race/ethnicity, gender, age, school type, educational level, and educational experience.

Table 2. Participating Teachers' Demographic Data

\begin{tabular}{lll}
\hline Variables & Frequency $(n)$ & Percent $(\%)$ \\
\hline Race/Ethnicity & 2 & 0.6 \\
American Indian or Alaskan Native & 46 & 14.6 \\
Black or African American & 3 & 1.0 \\
Hispanic or Latino or Spanish Origin & 263 & 83.8 \\
White & 253 & 81 \\
Gender & 61 & 19 \\
Female & & \\
Male & & \\
Age & 34 & 11 \\
29 Years or Fewer & 83 & 26 \\
30 - 39 Years & 93 & 30 \\
40 - 49 Years & 78 & 25 \\
50 - 59 Years & 26 & 8 \\
60+ Years & & \\
& 77 & 25 \\
School Type & 237 & 75 \\
Private & & \\
Public & 97 & 31 \\
Educational Attainment & 193 & 61 \\
Bachelor's Degree & 19 & 6 \\
Master's Degree & 5 & 2 \\
Educational Specialist Degree & & \\
Doctorate Degree & 38 & 12.1 \\
Educational Experience & 59 & 18.8 \\
Less than 1 Year & 50 & 26.8 \\
1 - 5 Years & 84 & 3.8 \\
6 - 10 Years & 71 & \\
11 - 15 Years & 12 & \\
16 - 20 Years & & \\
21+ Years & & \\
\hline
\end{tabular}

For the categorical variable, Race/Ethnicity, White $(n=263)$ was the largest percentage of participants $(83.8 \%)$. The majority of the participants were female $(n=253,81 \%)$, and males accounted for $19 \%(61)$. The majority of the participants were in public schools $(n=237,75 \%)$. The largest participating age category with 93 respondents $(30 \%)$ ranged from 40 to 49 years with fewer participants $(n=26)$ at $8 \%$ in the category who were 60 or more years of age. Although $61 \%(n=193)$ of the participants held a master's degree, only $2 \%(n=5)$ of the participants held a doctoral 
degree. The educational experience of 84 participants (26.8\%) ranged from 11-15 years, while 12 participants (3.8\%) worked 21 or more years.

\subsection{Results of Research Questions}

\section{Q1. To what extent do teachers perceive that principals exhibit Green's 13 core competencies?}

Measured on a Likert scale (i.e., total sum of responses to several Likert items) with a score from 1 to 5, Table 3 lists the descriptive statistics for teachers' perceptions of principals exhibiting the 13 core competencies.

Table 3. Teachers' Perceptions of Principals exhibiting the Thirteen Core Competencies

\begin{tabular}{lll}
\hline Variables & $M$ & $S D$ \\
\hline Professionalism & 4.68 & 0.64 \\
Curriculum and Instruction & 4.57 & 0.69 \\
Diversity & 4.57 & 0.69 \\
Collaboration & 4.55 & 0.74 \\
Assessment & 4.54 & 0.63 \\
Unity of Purpose & 4.51 & 0.70 \\
Learning Community & 4.49 & 0.75 \\
Reflection & 4.47 & 0.71 \\
Visionary Leadership & 4.46 & 0.76 \\
Organizational Management & 4.45 & 0.79 \\
Inquiry & 4.43 & 0.67 \\
Instructional Leadership & 4.36 & 0.79 \\
Professional Development & 4.20 & 0.89 \\
\hline
\end{tabular}

The data revealed that all core competencies perceived by 314 teachers were highly prevalent among principals. According to the mean $(M)$ and standard deviation $(S D)$, teachers reported that the five most observed core competencies were professionalism $(M=4.68, S D=0.64)$, curriculum and instruction $(M=4.57, S D=0.69)$, diversity $(M=4.57, S D=0.69)$, collaboration $(M=4.55, S D=0.74)$, and assessment $(M=4.54, S D=0.63)$.

Extending the research, Table 4 gives the complete summary of an independent sample $t$-test analysis of teachers' perceptions of principals exhibiting the 13 core competencies.

Table 4. Independent Sample t-Test Analyses: Teachers' Perceptions of Principals exhibiting the Thirteen Core Competencies

\begin{tabular}{llllllll}
\hline & & & & & Private & \multicolumn{3}{l}{ Public } \\
\hline Variables & $t(312)$ & $p$ & Cohen's $d$ & $M$ & $S D$ & $M$ & $S D$ \\
\hline Assessment & -4.91 & .000 & 0.64 & 4.19 & 0.74 & 4.65 & 0.54 \\
Collaboration & -2.95 & .004 & 0.39 & 4.29 & 0.97 & 4.63 & 0.62 \\
Curriculum and Instruction & -2.33 & .022 & 0.31 & 4.37 & 0.97 & 4.64 & 0.56 \\
Diversity & -1.14 & .256 & 0.15 & 4.49 & 0.85 & 4.59 & 0.64 \\
Inquiry & -5.42 & .000 & 0.71 & 4.03 & 0.82 & 4.57 & 0.55 \\
Instructional Leadership & -4.46 & .000 & 0.59 & 3.96 & 0.96 & 4.49 & 0.69 \\
Learning Community & -2.56 & .012 & 0.34 & 4.27 & 0.94 & 4.56 & 0.66 \\
Organizational Management & -2.62 & .010 & 0.34 & 4.21 & 1.00 & 4.53 & 0.70 \\
Professional Development & -4.18 & .000 & 0.55 & 3.77 & 1.09 & 4.33 & 0.77 \\
Professionalism & 0.16 & .875 & 0.02 & 4.69 & 0.80 & 4.68 & 0.58 \\
Reflection & -2.31 & .022 & 0.30 & 4.31 & 0.86 & 4.52 & 0.65 \\
Unity of Purpose & -2.78 & .007 & 0.36 & 4.27 & 0.92 & 4.58 & 0.59 \\
Visionary Leadership & -2.53 & .013 & 0.33 & 4.25 & 0.88 & 4.53 & 0.71 \\
\hline
\end{tabular}

The $t$-test evaluated whether the mean value of the test variables (i.e., core competencies) for one group (i.e., public teachers) differed significantly from the mean value of the test variables for the second group (i.e., private teachers). Because the $p$-value was less than .05 ( $p<.05$, two-tailed), the researcher found that 11 of the 13 core competencies were significantly different among the perceptions of private $(M=77)$ and public teachers $(M=237)$ towards their principals exhibiting Green's 13 core competencies. Public teachers believed that their principals exhibited behaviors informed by assessment, collaboration, curriculum and instruction, inquiry, instructional leadership, learning community, organizational management, professional development, reflection, unity of purpose, and visionary leadership to a greater extent than private teachers did. Furthermore, the overlapping confidence intervals of the competencies revealed that public teachers' perceived that public school principals exhibited the core competencies heavily within their schools' organizational structure (i.e., core competencies were interconnected).

Diversity $(p=.256)$ and Professionalism $(p=.875)$ were the only core competencies greater than the set $p$-value; therefore, they were not significant. The core competency, Assessment, was significantly different among public teachers' perceptions from private. The independent $t$-test revealed the significant level of Assessment as $t(312)=-4.91$, $p<.001, d=0.64$. The $95 \%$ confidence intervals (CI) for Assessment mean ranged from -.63 to -.27 . The group means 
indicated that public teachers' perceptions of Assessment $(M=4.65, S D=0.54)$ among public principals were greater than private teachers' perceptions $(M=4.19, S D=0.74)$. Professional development, $t(312)=-4.18, p<.001, d=0.55$, 95\% CI [-.83, -.29], showed a statistically significant difference between the two groups and was higher among public teachers $(M=4.33, S D=0.77)$. Diversity, $t(312)=-1.14, p=.256, d=0.15,95 \%$ CI $[-.28, .08]$, was not significantly different between the two groups of teachers, but was higher among public teachers' perceptions $(M=4.59, S D=0.64)$. Professionalism, $t(312)=.16, p=.875, d=0.02,95 \% \mathrm{CI}[-.15, .18]$, was not significantly different among teachers, but was higher among private teachers' perceptions $(M=4.69, S D=0.80)$.

To guard against an inflated family-wise error (i.e., Type I Error - incorrect rejection of a true null hypothesis), a Bonferroni correction was used to adjust the $p$-value $(p<.05)$ and test for significance. Applying the Bonferroni correction, the Bonferroni critical value was $p=.004$ (rounded). According to the new threshold value of $p \leq .004$ that is reported typically under the rounded criterion, the researcher concluded that only five of the 13 core competencies (i.e., assessment, collaboration, inquiry, instructional leadership, and professional development) were significantly different among private and public teachers.

\section{Q2. Is there a relationship between teachers' perceptions of school climate and Green's $\mathbf{1 3}$ core competencies?}

In Table 5, the Pearson product-moment correlation was used to determine if there was a relationship between 314 teachers' perceptions of school climate and Green's 13 core competencies. The analyses yielded moderately strong positive correlations $(.60<r<.76)$. There was a positive relationship between school climate and each core competency. Since the school climate and each of the 13 core competencies had significant levels of $p=.000$ and was less than the set level of significance $(p<.01)$, the researcher concluded that correlations existed between school climate and the core competencies.

Table 5. Pearson Correlation of Teachers' Perceptions of School Climate and the Thirteen Core Competencies

\begin{tabular}{ll}
\hline Variables & School Climate \\
\hline Assessment & $.60^{* *}$ \\
Collaboration & $.71^{* *}$ \\
Curriculum and Instruction & $.72^{* *}$ \\
Diversity & $.76^{* *}$ \\
Inquiry & $.62^{* *}$ \\
Instructional Leadership & $.68^{* *}$ \\
Learning Community & $.73^{* *}$ \\
Organizational Management & $.76^{* *}$ \\
Professional Development & $.69^{* *}$ \\
Professionalism & $.69^{* *}$ \\
Reflection & $.73^{* *}$ \\
Unity of Purpose & $.73^{* *}$ \\
Visionary Leadership & $.74^{* *}$ \\
\hline
\end{tabular}

$* * p<.01$, two-tailed

The correlations between the core competencies and school climate were as follows: (a) assessment $(r=.60, p<.001)$, (b) collaboration $(r=.71, p<.001)$, (c) curriculum and instruction $(r=.72, p<.001)$, (d) diversity $(r=.76, p<.001)$, (e) inquiry $(r=.62, p<.001)$, (f) instructional leadership $(r=.68, p<.001)$, (g) learning community $(r=.73, p<.001)$, (h) organizational management $(r=.76, p<.001)$, (i) professional development $(r=.69, p<.001)$, (j) professionalism $(r$ $=.69, p<.001)$, (k) reflection $(r=.73, p<.001)$, (l) unity of purpose $(r=.73, p<.001)$, and (m) visionary leadership $(r$ $=.74, p<.001)$. Additionally, the Pearson correlation analyses also revealed that organizational management and learning community $(r=.91, p<.001)$, organizational management and visionary leadership $(r=.88, p<.001)$, organizational management and collaboration $(r=.86, p<.001)$, and unity of purpose and visionary leadership $(r=.86$, $p<.001)$ exhibited the strongest correlations to school climate.

According to the data, the more teachers perceived that their school climate was positive, the more likely the school leader exhibited the core competencies. An increase in the core competencies was correlated to an increase in school climate. A significant positive correlation indicated that as one variable increased, the other variable also inclined to increase. The researcher found that each core competency had a positive relationship on the other, which gave stronger evidence to why the school climate and the competencies had a positive relationship.

\section{Q3. Which of Green's 13 core competencies has the largest impact on school climate?}

Table 6 displays a multiple regression analysis using stepwise modeling to determine which of Green's 13 core competencies had the largest impact on school climate. The stepwise process analyzed the data within the correlation matrix and elected the variable that had the largest Pearson Correlation with the dependent variable, school climate. When the variable was predicted, the regression analysis captured the variable, and the process was repeated until all 
independent predictors were found, giving them an appropriate model status (i.e., Model 1, Model 2, etc.). When the modeling process discovered a non-significant predictor, the analysis ended. The probability criteria for entry and removal of the independent variables (i.e., assessment, collaboration, curriculum and instruction, diversity, inquiry, instructional leadership, learning community, organizational management, professional development, professionalism, reflection, unity of purpose, and visionary leadership) from the stepwise analysis allowed for the precise impacting variables to be revealed. After entering the independent variables, the regression analysis determined that diversity, professional development, and professionalism were the best predictor variables impacting school climate.

Table 6. Multiple Regression Analysis: Core Competencies Impacting School Climate

\begin{tabular}{llllllll}
\hline & & & & & \multicolumn{3}{c}{$95 \%$ CI for $B$} \\
\cline { 6 - 8 } Predicator Variables & $\beta$ & $S E B$ & $B$ & $t$ & $p$ & Lower & Upper \\
\hline Diversity & .26 & .04 & .39 & 7.08 & .000 & .19 & .33 \\
Professional Development & .15 & .02 & .30 & 6.62 & .000 & .11 & .20 \\
Professionalism & .17 & .04 & .24 & 4.81 & .000 & .10 & .24 \\
\hline
\end{tabular}

$F(3,310) \stackrel{\text { Professionalism }}{=201.56, p<.001, R^{2}=.66}$

Diversity, Model 1, accounted for $58 \%\left(\Delta R^{2}=.58, F(1,312)=425.54, p<.001\right)$ of the variance in school climate. Model 2 predictor variable, professional development, increased the variance in school climate to $63 \%\left(\Delta R^{2}=.63, F(2\right.$, $311)=271.49, p<.001)$. The final analysis of the linear regression was significant. Model 3, Professionalism, incorporating both Model 1 and Model 2, accounted for $66 \%\left(\Delta R^{2}=.66, F(3,310)=201.56, p<.001\right)$ of the variance in school climate. Professional development was a significant predictor of school climate, $\beta=0.15, p<.001$, suggesting that for every one unit increase in professional development, school climate increased by 0.15 units. Professionalism was a significant predictor of school climate, $\beta=0.17, p<.001$, suggesting that for every one-unit increase in professionalism, school climate increased by 0.17 units. After examining the unstandardized beta coefficients, diversity was the most significant predictor to affect school climate, $\beta=0.26, p<.001$, suggesting that for every one unit increase in diversity, school climate increased by 0.26 units.

Teachers recognized that the school's climate reflected the physical, social, affective, and academic environments of a school. Additionally, teachers perceived that their principals valued diversity (i.e., ideas, support, etc.) and empowered every stakeholder in a professional setting, which led to quality professional development experiences directed by diverse professionals. When the core competencies were exhibited, principal's empowerment sessions improved the school's climate and culture.

\section{Q4. Do perceptions of school climate differ between private and public teachers?}

An independent $t$-test determined whether significant differences existed by comparing the means between two groups on the same continuous, dependent variable (Creswell, 2015). Using a set significant level of $p<.05$ (two-tailed) in Table 7, the researcher concluded that there was no difference in the perceptions of 77 private school teachers $(M=3.61$, $S D=0.51)$ and 237 public school teachers $(M=3.66, S D=0.45)$ regarding school climate.

The assumption of normality was assessed using a Shapiro-Wilk test $(p<.05)$. The Shapiro-Wilk test was not the only test to determine normality and was used in conjunction with the examination of histograms, skewness, kurtosis, and Q-Q plots. Tabachnick and Fidell (2007) reported that conventional alpha levels, $\alpha=.01$ and $\alpha=.001$, are commonly used to test the assumption of normality. The results of the Shapiro-Wilk test revealed significance, $p<.001$, violating the assumption of normality. The data were not normally distributed (e.g., in the shape of a bell curve).

The Levene's $F$ test for equality of variance and the set level of significance, $\alpha=.05$, are the most commonly used statistical factors for testing the assumption of homogeneity of variance (Gastwirth, Gel, \& Miao, 2009). As the analysis continued using the independent sample $t$-test, Levene's $F$ test assessed the assumption of equality of variance. The test took into consideration that the null hypothesis $\left(H_{0}\right)$ assumed no difference between the groups' (private and public teachers) variances $\left(H_{0}: \sigma_{1}^{2}=\sigma^{2}{ }_{2}\right)$. When the results of the test were not met, the current data were applied to the equal variances not assumed. When the results of the test were met, current data were applied to the equal variances assumed (Gastwirth et al., 2009).

The result of the test was not significant, $p=.813$, indicating the assumption of equality of variance was met. The probability value of equality of variance, $p=.813$, was greater than the set probability or significance level (i.e., alpha or $\alpha$ ) of $\alpha=.05$ assuming equal variance between the perceptions of private and public teachers. For the purpose of continuous analysis, the results of the $t$-test for the equality of means (i.e., the $t$-value and the degree of freedom) were utilized for the equal variances assumed. Since the significant probability for the equality of means, $p=.459$, was greater than the probability or significance level of $\alpha=.05$, results of the $t$-test were not statistically significant. Table 7 shows the perceptions of public and private teachers on school climate. 
Table 7. Independent Sample t-Test Analysis: Perceptions of Public and Private School Teachers on School Climate

\begin{tabular}{llllllll}
\hline Variable & $t(312)$ & $p$ & Cohen's $d$ & & Private & \multicolumn{3}{c}{ Public } \\
\hline $\begin{array}{l}\text { School } \\
\text { Climate }\end{array}$ & -0.74 & .459 & 0.09 & 3.61 & 0.51 & 3.66 & 0.45
\end{tabular}

Results from the independent sample $t$-test failed to confirm the hypothesis that private and public teachers' perceptions differed in regards to school climate. School climate, $t(312)=-.74, p=.459, d=0.09,95 \%$ CI [-.16, .07], was not significantly different between private and public teachers. Both public and private teachers perceived that their principals addressed concerns about teaching and learning, had high expectations, and helped to create a school environment that was safe and orderly. Teachers perceived that principals valued and respected their ideas, which provided the foundation for participation in a fair, democratic teaching and learning environment, thereby improving the school climate. Since significantly different perceptions were not revealed, the researcher concluded the following among their principals: (1) strong administrative skills, (2) exceptional educational background (i.e., diverse in subject matter and hiring highly qualified teachers to teach), (3) healthy interpersonal connectedness (i.e., positive relationships between teachers, students, and other stakeholders), and (4) bold environmental connectedness (i.e., concerns between the school environment and community).

\section{Discussion and Conclusion}

The current study uncovered teachers' perceptions of principals exhibiting Green's 13 core competencies within private and public schools. The descriptive data revealed that all core competencies perceived by teachers were highly prevalent among principals. Teachers reported that the five most observed core competencies were professionalism, curriculum and instruction, diversity, collaboration, and assessment. Although the mean values of the competencies were relatively close, an unexpected outcome emerged such that visionary and instructional leaderships did not rank as the most prevalent behaviors influencing the schools' organizational structure.

Results from an independent sample $t$-test revealed that 11 of the 13 core competencies were statistically different between private and public teachers, but failed to find statistically significant differences in diversity and professionalism. However, the researcher concluded that only five of the 13 core competencies were significant using the Bonferroni correction method. Additionally, an independent sample $t$-test failed to confirm that the perceptions of private and public teachers' differed in regards to school climate.

A multiple regression analysis revealed that diversity was the largest core competency influencing school climate followed by professional development and professionalism. According to the competencies (i.e., diversity, professional development, and professionalism) influencing school climate, an independent sample $t$-test revealed that professional development was statistically significant and higher among public teachers' perceptions than private teachers' perceptions. These higher perceptions among public teachers could be due to the following: (1) extensive professional development, (2) rigorous demands governed by superintendents or board members placed on public principals to understand their administrative efforts, and (3) leadership behaviors influencing teaching, learning, building collective teacher effectiveness, and implementing policies and strategies outlined according to state guidelines.

Findings from the Pearson correlation analyses determined that there were relationships between teachers' perceptions of school climate and Green's 13 core competencies and that the relationship yielded positive results. The data revealed that the competencies were connected such that they directly influenced the school's climate (i.e., increasing one competency would increase the other, but decreasing one would decrease the other). When teachers positively perceived their principals' leadership, they were also more likely to have higher perceptions of their school's climate.

The goals of instructional leaders are to increase the school's climate and culture through effective leadership skills and instructional best practices stimulating student achievement (Fullan, 2006; Leithwood et al., 2004; Spillane, 2006). Effective leadership behaviors enable principals to identify core competencies that connect with teachers' differentiated classroom instruction that pinpoints the students' strengths, weaknesses, and needs in order to adapt to the individualized learner (Dunn, 2012; Edudemic Staff, 2014; Muthler, 2015; Sergiovanni, 1984, 1999, 2005). Leadership practices that are capable of addressing quality instruction also have the potential to increase the school's climate and teacher effectiveness. Quality classroom instruction involves differentiated curriculum and instruction that centers around a variety of assessments, appropriate models for educational success, and higher order thinking questions that attract learners to the lessons (Dunn, 2012; Edudemic Staff, 2014; Muthler, 2015). To achieve academic goals, principals also need to adjust their leadership practices to be more conducive to innovation, collaboration, reflection, diversity, and professionalism. Although policymakers, board directors, and superintendents exemplify leadership behaviors according to their principles, school administrators are ultimately the critical constituents who support teachers, student achievement, and school climate. 
School leadership has significant effects on students' achievement, and job satisfaction promotes academic growth. The school principal should demonstrate quality leadership behaviors in a manner that is consistent throughout the school and community in an effort to build trust and support from various stakeholders. Strong educational leaders bring clear and compelling plans and organize people to achieve the goals through the execution of plans. "A leader's job is to cultivate and amass the intellectual capital needed for the school's organizational IQ to increase....That is why leadership and learning together are so important" (Sergiovanni, 2005, p. 122). Effective school leaders must support their teams to do their best, restructure the organization to improve effectiveness, and share responsibility as data driven-leaders. Perceptions in the workplace are often underestimated but can be key factors to success by encouraging others and preventing barriers. Perceptions do not necessarily reflect the reality, but it is important to collect authentic and accurate data from school personnel to measure workplace conditions on a regular basis.

\section{Acknowledgement}

Katherine Cozzens - Editor and Educator for Collierville Schools, Collierville, TN.

\section{References}

Afshari, M., Bakar, K., Luan, W., \& Siraj, S. (2012). Factors affecting the transformational leadership role of principals in implementing ICT in schools. The Turkish Online Journal of Educational Technology, 11(4), 164-176.

Aydin, A., Sarier, Y., \& Uysal, S. (2013). The effect of school principal's leadership styles on teachers' organizational commitment and job satisfaction. Educational Sciences: Theory and Practice, 13(2), 806-811.

Bass, B. M. (1985). Leadership and performance beyond expectation. New York: Free Press.

Bass, B. M., \& Avolio, B. J. (1994). Improving organizational effectiveness through transformational leadership. Thousand Oaks, CA: Sage.

Bass, B. M., \& Riggio, R. E. (2006). Transformational leadership. New York: Psychology Press.

Blasé, J., \& Blasé, J. (1998). Handbook of instructional leadership: How really good principals promote teaching and learning. Thousand Oaks, CA: Corwin Press.

Boerner, S., Eisenbeiss, S. A., \& Griesser, D. (2007). Follower behavior and organizational performance: The impact of transformational leaders. Journal of Leadership and Organizational Studies, 13(3), 15-26. http://dx.doi.org/10.1177/10717919070130030201

Bossert, S. T., Dwyer, D. C., Rowan, B., \& Lee, G. V. (1982). The instructional management role of the principal. Educational Administration Quarterly, 18(3), 34-64. http://dx.doi.org/10.1177/0013161X82018003004

Bruce, M. (2011, September 23). Obama: 'No child left behind' changes will allow states to meet higher standards. Retrieved September 10, 2014, from

http://abcnews.go.com/blogs/politics/2011/09/obama-no-child-left-behind-changes-will-allow-states-to-meet-highe r-standards/

Burns, J. M. (1978). Leadership. New York: Harper-Rowe.

Calik, T., Sezgin, F., Kavgaci, H., \& Kilinc, A. (2012). Examination of relationships between instructional leadership of school principals and self-efficacy of teachers and collective teacher efficacy. Educational Sciences: Theory \& Practice, 12(4), 2498-2504.

Capelluti, J., \& Nye, K. (2004). The eight habits of highly ineffective principals. NASSP. Retrieved October 16, 2015, from http://theprincipalship.wikispaces.com/file/view/The+8+Habits+of+Highly+Ineffective+Principals.pdf

Cohen, J., McCabe, E. M., Michelli, N. M., \& Pickeral, T. (2009). School climate: Research, policy, practice, and teacher education. Teachers College Record, 111(1), 180-213. Retrieved January 3, 2015, from http://www.schoolclimate.org/climate/documents/policy/School-Climate-Paper-TC-Record.pdf

Cook, J. (2014). Sustainable school leadership: The teachers' perspective. International Journal of Educational Leadership, 9(1), 1-17.

Copland, M. (2000). Leadership of inquiry: Building and sustaining capacity for school improvement. Educational Evaluation and Policy Analysis, 25(4), 375-395. http://dx.doi.org/10.3102/01623737025004375

Cotton, K. (2000). The schooling practices that matter most. Alexandria, VA: Association for Supervision and Curriculum Development.

Cozzens, J. (2004). The Influence of School Climate of Selected Schools Facing Consolidation. (Unpublished doctoral dissertation). Memphis, TN: University of Memphis.

Creswell, J. W. (2015). Educational research: planning, conducting, and evaluating quantitative and qualitative 
research $\left(5^{\text {th }}\right.$ ed.). Upper Saddle River, NJ: Pearson Education.

Danielson, C. (2006). Teacher Leadership: That strengthens professional practice. Alexandria, VA: Association for Supervision and Curriculum Development.

Dawson, C., \& Rakes, G. (2003). The influence of principles' technology training on the integration of technology into schools. Journal of Research on Technology in Education, 36(1), 29-49. http://dx.doi.org/10.1080/15391523.2003.10782401

DuFour, R., Eaker, R., \& Burnett, R. (2002). Getting started: Reculturing schools to become professional learning communities. Bloomington, IN: National Educational Service.

Dunn, J. (2012, May). To flip or not flip? Edudemic - Connecting Education and technology. Retrieved July 26, 2015, from http://www.edudemic.com/to-flip-or-not-flip-your-classroom/

Editorial Projects in Education Research Center. (2011a, June 29). Issues A-Z: Professional Development. Education Week. Retrieved January 2, 2015, from http://www.edweek.org/ew/issues/professional-development/

Editorial Projects in Education Research Center. (2011b, September 19). Issues A-Z: No Child Left Behind. Education Week. Retrieved August 20, 2014, from http://www.edweek.org/ew/issues/no-child-left-behind/

Edmonds, R. (1979). Effective schools for the urban poor. Educational Leadership, 37, 15-24. Retrieved November 20, 2014, from http://www.ascd.org/ASCD/pdf/journals/ed_lead/el_197910_edmonds.pdf

Edudemic Staff. (2014, November). Delivering differentiated instruction in your classroom. Edudemic-Connecting Education and Technology. Retrieved July 26, 2015, from http://www.edudemic.com/delivering-differentiated-instruction/

Farmer, A. W. (2010). The perception of teachers and principals on leaders' behavior informed by 13 core competencies and its relationship to teacher motivation. (Unpublished doctoral dissertation). Memphis, TN: University of Memphis.

Friend, M., \& Cook, L. (2009). Interactions: Collaboration skills for school professional (6 ${ }^{\text {th }}$ ed.). Upper Saddle River, NJ: Prentice Hall.

Fullan, M. (2006). The development of transformational leaders for educational decentralization. Toronto: Canada.

Gastwirth, J., Gel, Y., \& Miao, W. (2009). The impact of Levene's test of equality of variances on statistical theory and practice. Statistical Science, 24(3), 343-360. http://dx.doi.org/10.1214/09-STS301

Gray, D., \& Lewis, J. (2013). Lessons learned in preparing principals to become instructional leaders. International Journal of Educational Leadership Preparation, 8(1), 140-143.

Green, R. L. (1998). Nurturing characteristics in schools related to discipline, attendance, and eighth grade proficiency test scores. American Secondary Education, 26(4), 7-14.

Green, R. L. (2001). Practicing the art of leadership: A problem-based approach to implementing the ISLLC standards. Upper Saddle River, NJ: Merrill Prentice-Hall.

Green, R. L. (2006). Leadership behavior inventory. Memphis, TN: University of Memphis.

Green, R. L. (2010). The four dimension of principal leadership: A framework for leading $21^{\text {st }}$ century schools. Boston: Allyn \& Bacon.

Green, R. L. (2012). Practicing the art of leadership: A problem-based approach to implementing the ISLLC standards ( $4^{\text {th }}$ ed.). Upper Saddle River, NJ: Merrill Prentice-Hall.

Green, R. L. (2014). Leadership behavior inventory. Memphis, TN: University of Memphis.

Gupton, S. L. (2003). The instructional leadership toolbox: A handbook for improving Practice. Thousand Oaks, CA: Corwin Press.

Hallinger, P. (1992). The evolving role of American principals: From managerial to instructional to transformational leaders. Journal of Educational Administration, 30(3), 35-48. http://dx.doi.org/10.1108/09578239210014306

Hallinger, P. (2003, November). Leading educational change: Reflections on the practice of instructional and educational leadership. Cambridge Journal of Education, 33(3), 329-351. http://dx.doi.org/10.1080/0305764032000122005

Hallinger, P., \& Heck, R. H. (2010, April). Collaborative leadership and school improvement: understanding the impact on school capacity and student learning. School Leadership and Management, 30(2), 95-110. http://dx.doi.org/10.1080/13632431003663214

Hoerr, T. (2005). The art of school leadership. Alexandria, VA: Association for Supervision and Curriculum 
Development.

Hoy, W. K., Sweetland, S. R., \& Smith, P. A. (2002). Toward an organizational model of achievement in high schools: The significance of collective efficacy. Educational Administration Quarterly, 38(1), 77-93. http://dx.doi.org/10.1177/0013161X02381004

Hull, J. W. (2002, June). The No Child Left Behind Act of 2001: Leaving the States behind. Retrieved September 3, 2014, from http://www.slcatlanta.org/Publications/Education/NoChildLeftBehind.PDF

Interstate School Leader Licensure Consortium Standards (2008). Educational Leadership Policy Standards: ISLLC 2008. Washington, D.C.: Council of Chief State School Officers. Retrieved on October 9, 2014, from http://www.ccsso.org/Documents/2008/Educational_Leadership_Policy_Standards_2008.pdf

Interstate School Leader Licensure Consortium Standards (2014). Educational Leadership Policy Standards: ISLLC 2014. Washington, D.C.: Council of Chief State School Officers. Retrieved on January 31, 2014, from http://blogs.edweek.org/edweek/District_Dossier/Draft\%202014\%20ISLLC\%20Standards\%2009102014.pdf

Ivie, S. (2007). School leaders' behavior informed by thirteen core leadership competencies and the relation to teacher job satisfaction. (Unpublished doctoral dissertation). Memphis, TN: University of Memphis.

Kelley, R. C., Thornton, B., \& Daugherty, R. (2005). Relationships between measures of leadership and school climate. Education, 126(1), 17-25. Retrieved November 25, 2014, from http://donnieholland.wiki.westga.edu/file/view/relationship+bw+school+climate+\%26+leadership.pdf

Lambert, L. (1998). Building leadership capacity in schools. Alexandria, VA: Association for Supervision and Curriculum Development.

Lambert, L. (2002, May). Beyond instructional leadership: A framework for shared leadership. Educational Leadership, 59(8), $\quad 37-40 . \quad$ Retrieved July 2014 , 14, from http://www.ascd.org/publications/educational-leadership/may02/vol59/num08/A-Framework-for-Shared-Leadershi p.aspx

Lambert, L. (2006, Spring). Lasting leadership: A study of high leadership capacity schools. The Education Forum, 70, 238-254. http://dx.doi.org/10.1080/00131720608984900

Leithwood, K. (1992). The move toward transformational leadership. Educational Leadership, 49(5), 8-12.

Leithwood, K., \& Jantzi, D. (2006). Transformational school leadership for large-scale reform: Effects on students, teachers, and their classroom practices. School Effectiveness and School Improvement, 17(2), 201-227. http://dx.doi.org/10.1080/09243450600565829

Leithwood, K., Louis, K., Anderson, S., \& Wahlstrom, K. (2004, September). How leadership influences student learning. New York: The Wallace Foundation. Retrieved August 1, 2014, from http://www.wallacefoundation.org/knowledge-center/school-leadership/key-research/Documents/How-LeadershipInfluences-Student-Learning.pdf

Levine, A. (2005). Educating school leaders. The Education Subjects Project. Retrieved July 26, 2014, from http://www.edschools.org/pdf/ESfinal313.pdf

Levine, T., \& Marcus, A. (2007). Closing the achievement gap through teacher collaboration: Facilitating multiple trajectories of teacher learning. Journal of Advanced Academics, 19(1), 116-138.

Liontos, L. B. (1992). Transformational leadership. Eugene, OR: ERIC Clearinghouse on Educational Management. Retrieved December 15, 2014, from http://www.vtaide.com/png/ERIC/Transformational-Leadership.htm

Lohman, J. (2010). Comparing No Child Left Behind and Race to the Top (OLR Research Report 2010-R-0235). Retrieved October 16, 2015, from https://www.cga.ct.gov/2010/rpt/2010-R-0235.htm

Louis, K., Dretzke, B., \& Wahlstrom, K. (2010, September). How does leadership affect student achievement? Results from a national US survey. School Effectiveness and School Improvement, 21(3), 315-336. http://dx.doi.org/10.1080/09243453.2010.486586

Louis, K., Leithwood, K., Wahlstrom, K., \& Anderson, S. (2010). Learning from Leadership: Investigating the links to improved student learning. Final report of research to the Wallace Foundation. Retrieved October 17, 2015, from the University of Minnesota, Center for Applied Research and Educational Improvement website: http://www.wallacefoundation.org/knowledge-center/school-leadership/key-research/Documents/Investigating-theLinks-to-Improved-Student-Learning.pdf

MacNeil, A., Prater, D., \& Busch, S. (2009). The effects of school culture and climate on student achievement. International Journal of Leadership in Education, 12(1), 73-84. http://dx.doi.org/10.1080/13603120701576241 
Marks, H., \& Printy, S. (2003). Principal leadership and school performance. An integration of transformational and instructional leadership. Educational Administration Quarterly, 39(3), 370-397. http://dx.doi.org/10.1177/0013161X03253412

Marzano, R., Waters, T., \& McNulty, B. (2005). School leadership that works: From research to results. Alexandria, VA: Association of Supervision and Curriculum Development.

Mendels, P. (2012). The effective principal. Leaning Forward, 33(1), 1-4. Retrieved December 7, 2014, http://www.wallacefoundation.org/knowledge-center/school-leadership/effective-principal-leadership/Documents/ The-Effective-Principal.pdf

Miller, T., \& Hanna, R. (2014, March). Four years later, are race to the top states on track. Retrieved October 16, 2015 from Center for American Progress website:

https://www.americanprogress.org/issues/education/report/2014/03/24/86197/four-years-later-are-race-to-the-top-st ates-on-track/

Murphy, J., Elliot, S., Goldring, E., \& Porter, A. (2007, April). Leadership for learning: A research-based model and taxonomy of behaviors. Journal of School Leadership and Management, 27(2), 179-201. http://dx.doi.org/10.1080/13632430701237420

Muthler, S. (2015, February). Differentiation isn't perfect - but it can work. Edudemic-Connecting Education and Technology. Retrieved July 26, 2015, from http://www.edudemic.com/differentiation-can-work/

National School Climate Council (2007). The School Climate Challenge: Narrowing the gap between school climate research and school climate policy, practice guidelines and teacher education policy. Retrieved October 23, 2014, from http://schoolclimate.org/climate/documents/school-climate-challenge.pdf

No Child Left Behind (NCLB) Act of 2001, Pub. L. No. 107-110, § 115, Stat. 1425 (2002). Retrieved August 1, 2014, http://www2.ed.gov/policy/elsec/leg/esea02/107-110.pdf

Powell, D., Higgins, H., Aran, R., \& Freed, A. (2009). Impact of No Child Left Behind on curriculum and instruction in rural schools. The Rural Educator, 31(1), 19-28.

Printy, S. M. (2008). How do principals influence teaching practices that make a difference for student achievement. Retrieved November 5, 2014, from https://research.vancouver.wsu.edu/sites/research.vancouver.wsu.edu/files/Printy.pdf

Riggio, R. E. (2009, March 24). Are you a transformational leader. Psychology Today. Retrieved December 28, 2014, from https://www.psychologytoday.com/blog/cutting-edge-leadership/200903/are-you-transformational-leader

Robinson, V., Lloyd, C., \& Rowe, K. (2008). The impact of leadership on student outcomes: An analysis of the differential effects of leadership types. Educational Administration Quarterly, 44(5), 635-674. http://dx.doi.org/10.1177/0013161X08321509

Ross, J., \& Gray, P. (2006a). Transformational leadership and teacher commitment to organizational values: The mediating effects of collective teacher efficacy. School Effectiveness and School Improvement, 17(2), 179-199. http://dx.doi.org/10.1080/09243450600565795

Ross, J., \& Gray, P. (2006b). School leadership and student achievement: The mediating effects of teacher beliefs. Canadian Journal of Education, 29(3), 798-822. http://dx.doi.org/10.2307/20054196

Rudd, H., Kent, T., Blair, C., \& Schuele, U. (2009). Leader behavior inventory: A test of measure equivalence in Germany and the United States. International Journal of Leadership Studies, 5(1), 22-36. Retrieved February 1, 2015 , from http://www.regent.edu/acad/global/publications/ijls/new/vol5iss1/IJLS_Vol5Is1_Rudd_et_al\%20(2)R.pdf

Santos, J. (1999). Cronbach's Alpha: A tool for assessing the reliability of scales. Journal of Extension, 37(2), 1-4. Retrieved February 1, 2015, from http://www.joe.org/joe/1999april/tt3.php

Schein, E. H. (1985). Organizational culture and leadership. San Francisco: Jossey-Bass Publishers.

Schein, E. H. (2004). Organizational culture and leadership (3rd ed.). San Francisco: John Wiley \& Sons.

Scott, A. (October, 2007). Sputnik-50 years later. Forum on Physics \& Society of The American Physical Society, 36(4), 1-9. Retrieved August 10, 2014, from http://www.aps.org/units/fps/newsletters/2007/october/scott.html

Sergiovanni, T. J. (1984). Leadership and excellence in schooling: Excellent schools need freedom within boundaries. Educational Leadership, 41(5), 4-13. Retrieved July 26, 2015, from

http://www.corwin.com/upm-data/11217_Serg__Article_1.pdf

Sergiovanni, T. J. (1999). Rethinking leadership: A collection of articles by Thomas J. Seriovanni. Arlington Heights, IL: 
SkyLight Training and Publishing.

Sergiovanni, T. J. (2005). The virtues of leadership. The Education Forum, 6, 112-123. http://dx.doi.org/10.1080/00131720508984675

Simpson, R. L., Lacava, P. G., \& Graner, P. S. (2004). The No Child Left Behind Act: Challenges and implications for educators. Intervention in School and Clinic, 40(2), 67-75. http://dx.doi.org/10.1177/10534512040400020101

Spellings, M. (2007). Building on results: A blueprint for strengthening the No Child Left Behind Act. Washington, DC: U.S. Department of Education. Retrieved August 20, 2014, from https://www2.ed.gov/policy/elsec/leg/nclb/buildingonresults.pdf

Spillane, J. (2006). Distributive leadership. San Francisco, CA: Jossey-Bass.

Standerfer, L. (2006). Before NCLB: The history of ESEA. Principal Leadership, 6(8), 26-27.

Stewart, J. (2006). Transformational leadership: An evolving concept examined through the works of Burns, Bass, Avolio, and Leithwood. Canadian Journal of Educational Administration Policy, 54, 1-29.

Straus, C. (2015). ESEA reauthorization: How we can build upon No Child's Left Behind progress for students with disabilities in a reauthorized ESEA. Retrieved from Center for American Progress website: https://www.americanprogress.org/issues/education/report/2015/04/02/110326/how-we-can-build-upon-no-child-le ft-behinds-progress-for-students-with-disabilities-in-a-reauthorized-esea/

Strauss, V. (2015, February 13). No Child Left Behind's test-based policies failed. Will Congress keep them anyway? The Washington Post. Retrieved April 26, 2015, from

https://www.washingtonpost.com/news/answer-sheet/wp/2015/02/13/no-child-left-behinds-test-based-policies-faile d-will-congress-keep-them-anyway/

Tabachnick, B. G., \& Fidell, L. S. (2007). Using multivariate statistics $\left(5^{\text {th }}\right.$ ed.). Needham Heights, MA: Allyn \& Bacon.

The White House. (2014, March). Setting the Pace: Expanding opportunity for America's students under race to the top. Retrieved September 10, 2014, from http://www.whitehouse.gov/sites/default/files/docs/settingthepacerttreport_3-2414_b.pdf

Trochim, W., \& Donnelly, J. (2008). The research methods knowledge base. Mason, OH: Cengage Learning. Tobin J. (2014). Management and leadership issues for school building leaders. International Journal of Educational Leadership Preparation, 9(1), 1-14.

U.S. Department of Education. (2004). A descriptive evaluation of the federal class-size reduction program: Final report. Office of the Deputy Secretary, Policy and Program Studies Service: Washington, D.C. Retrieved November 3, 2015, from http://www2.ed.gov/rschstat/eval/other/class-size/report.pdf

Villani, C. J. (1999). Community culture and school climate. The School Community Journal, 9(1), 103-105. Retrieved December 28, 2014, from http://www.adi.org/journal/ss99/VillaniSpring1999.pdf

Wahlstrom, K. L., \& Louis, K. S. (2008, October). How teachers experience principal leadership: The roles of professional community, trust, efficacy, and shared responsibility. Educational Administration Quarterly, 44(4), 458-495. http://dx.doi.org/10.1177/0013161X08321502

Ward, C. (2013). Why leadership matters: One school's journey to success. Educational Leadership and Administration: Teaching and Program Development, 24, 62-74.

Weaver, R. (2006). A positive agenda for ESEA. Educational Leadership, 64(3), 32-36.

Wiseman, R. (2014). Study finds that principals indirectly influence student learning in math by improving teacher collaboration and collective efficacy. The Elementary School Journal. Retrieved October 10, 2015, from http://www.press.uchicago.edu/pressReleases/2014/January/1401ESJprincipalsmath.html

Witziers, B., Bosker, R., \& Kruger, M. (2003). Educational leadership and student achievement: The elusive search for an association. Educational Administration Quarterly, 39(3), 398-425.

http://dx.doi.org/10.1177/0013161X03253411

\section{(cc) BY}

This work is licensed under a Creative Commons Attribution 3.0 License. 